\title{
COMMENTARY
}

\section{Messages from the morgue to rheumatology: from Chagas disease to giant cell arteritis}

Frank A Wollheim

\section{Abstract \\ Autopsy rates have fallen from over $50 \%$ to less than $10 \%$ in recent decades. The drastic decline creates uncertainty regarding causes of death and has negative effects for research, training, and patient safety, despite advances in imaging and laboratory testing. Rheumatology is as much at a loss as other specialties. Examples are given of important missed diagnoses revealed only at autopsy.}

When I was a medical school student in the 1950s and a resident and junior staff member in the 1960s and 1970s, regular visits to the morgue were an indispensable part of our workday routine. No first-class teaching hospital could operate without an adequate postmortem service. The contact between clinicians and pathologists in the morgue was an essential part of ultimate quality control and teaching and could stimulate collaborative research. In the city of Malmö, where the autopsy rate exceeded $80 \%$ of the population in the 1970 s, it is now less than $10 \%$. When I asked a resident when he last had been to a morgue, he answered 'I was there once when still a medical student'. Do the improved diagnostic instruments available today fully compensate for the lack of direct information given by careful autopsies, or are we missing valuable information by neglecting routine autopsy? All evidence indicates that we are indeed missing important information.

In the 1970s, a 65-year-old man received treatment for systemic sclerosis on the basis of skin thickening, dysphagia, constipation with abdominal pain, and cardiomegaly. Two days before Christmas Eve he died of heart failure. The next day, the professor in the morgue greeted us with a big smile: 'Today it is Christmas even here. I have today sectioned my first case of Chagas disease'. The patient, a

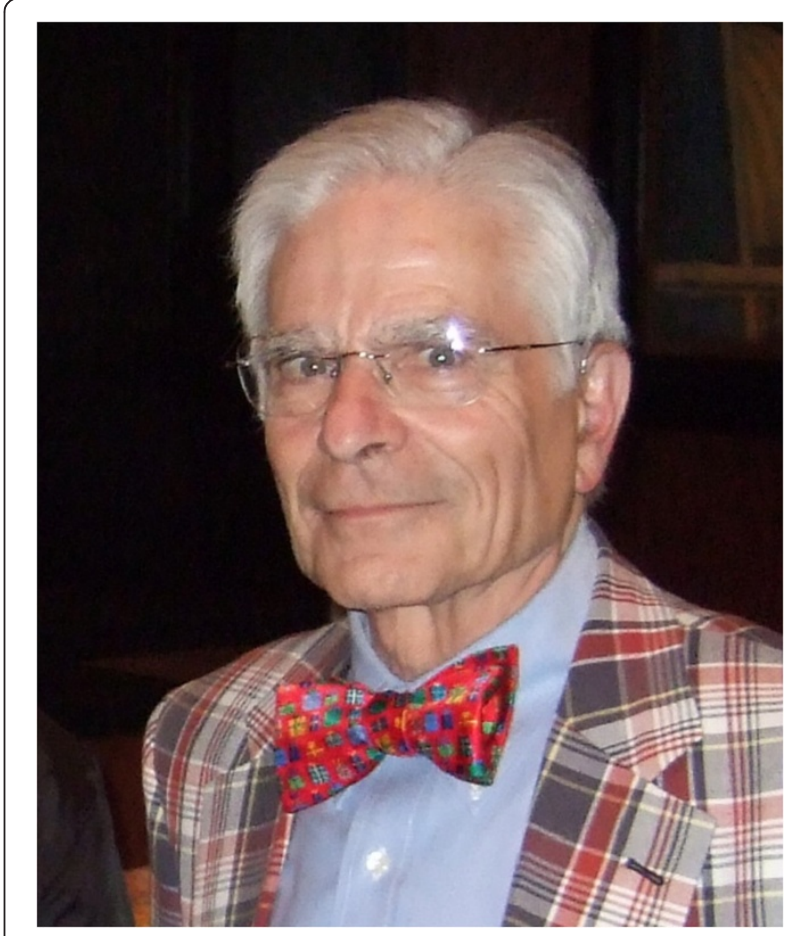

Box 1. About Frank Wollheim

Frank Wollheim is Emeritus Professor at the Department of Rheumatology, University of Lund. He was its chairman from 1982 to 1998 and started its programs in scleroderma, systemic lupus erythematosus, early rheumatoid arthritis, and biomarkers of arthritis. He trained in internal medicine with Jan Waldenström in Malmö and rheumatology with Ralph C Williams in Minneapolis before starting the first rheumatology unit in Malmö in 1972. He has served as Secretary General and board member of Osteoarthritis Research Society International and is a master member of the American College of Radiology. 
teacher, had spent time in Colombia, a fact the clinicians had paid little attention to. The physician in charge of the patient did research in scleroderma and learned a lesson for life.

Professor Kuntal Chakravarty, of Romford, UK, recently told me of a 36-year-old woman with a 5-year history of scleroderma who was admitted with acute abdominal pain, vomiting, and fever. X-rays and ultrasound did not reveal a cause. Owing to her scleroderma, the surgeons were reluctant to perform laparotomy, and she was treated with parenteral antibiotics and intravenous fluid. Her condition improved initially but later deteriorated and she died. The clinical diagnosis was peritonitis and ruptured intestine. The consulting rheumatologist $(\mathrm{KC})$ and the family insisted on an autopsy, which unexpectedly showed uncomplicated volvulus.

In 1975, we published an article on cause of death in 104 patients with rheumatoid arthritis (RA) based on routine post-mortem examination of patients during 5 years in a chronic care hospital in Malmö [1]. Cervical spine compression was identified as the cause of death in 11 patients. Only two of the cases had been diagnosed before death, although all patients had been hospitalized for months or years [1]. Although cervical spine instability is now rare, it still occurs and may be prevalent in communities with undeveloped health systems [2].

Very high autopsy rates generated accurate prevalence studies of atherosclerosis [3], thromboembolism [4] and cancer [5,6]. In 1969, when the autopsy rate was $65 \%$, Görel Östberg examined all 1,097 (!) temporal arteries from patients dying in 1 year in the city of Malmö, which had 250,000 inhabitants. The prevalence according to the literature was 2 out of 100,000 , but Östberg identified not fewer than 16 out of 1,000 patients with a male/female ratio of $6 / 10$. Only two of the patients had received a clinical diagnosis of temporal arteritis (retrospectively), and only a couple had suggestive symptoms [7]. Even more interesting is her systematic study of large vessel involvement in polymyalgia rheumatic and temporal arteritis, showing their overlap and coexisting polyarteritis nodosa and Takayasu's disease [8]. This work has recently been fully acknowledged and extended by Gary S Hoffman and the US Vasculitis Clinical Research Consortium [9].

In Finland, rheumatologists have published a number of articles illustrating substantial discrepancies between clinical and autopsy-based causes of death. In 36\% of 371 autopsied patients, significant infections were identified, only half of which had been diagnosed in vivo [10]. Amyloidosis was the cause of death in $9.5 \%$ of patients between 1950 and 1991; of these cases, 35\% had not been diagnosed in vivo [11]. Coronary heart disease showed an increasing prevalence in the same time period in the RA patients in contrast to autopsied non-RA patients and were likewise often not detected before death [12].

In the US, the autopsy rate dropped from above $70 \%$ in the 1960 s to $20 \%$ in 2005 at the Mayo Clinic and the Brigham and Women's Hospital. The overall rate in the US is now $4.3 \%$ in non-forensic cases [13]. Although advances in diagnostic tools have improved accuracy of clinical diagnostics, $8 \%$ of major errors were found in a systematic review of 53 publications [14]. Post-mortem imaging has been investigated as an alternative to autopsy [15]. An ambitions blinded comparison between computed tomography (CT), magnetic resonance imaging (MRI), and autopsy of 182 cases reported to the coroner between 2006 and 2008 showed that CT was as accurate as the clinical diagnosis but that nevertheless causes of sudden death were often missed. MRI was less accurate than CT [16]. Even in the context of experimental medicine, the trend is the same. In the Autologous Stem Cell Transplantation International Scleroderma trial of stem cell transplantation versus cyclophosphamide in diffuse systemic sclerosis, autopsy was performed in 7 out of 44 cases (Jaap van Laar, of Newcastle, UK, and Kamran Naraghi, of Middleborough, UK).

\section{Conclusions}

The decline in autopsy rates has several causes: diagnostic overconfidence, physician reluctance to pursue consent for autopsy, lack of regulatory requirements, public resistance, and budgetary constraints. Part of the problem is that doctors are short on time and motivating the family to agree to autopsy requires tact, time, and dedication. Reluctance to embark on the additional paper work may also contribute. Autopsy remains the gold standard for determining the cause of death [13], and although revitalizing it seems unrealistic, I feel a need to alert younger generations what they are missing, in rheumatology as in other specialties.

\section{Abbreviations \\ $\mathrm{CT}$ : Computed tomography; MRI: Magnetic resonance imaging; RA: Rheumatoid arthritis.}

\section{Competing interests}

The author declares that he has no competing interests.

\section{Published: 23 December 2013}

\section{References}

1. Mikulowski P, Wollheim FA, Rotmil P, Olsen I: Sudden death in rheumatoid arthritis with atlanto-axial dislocation. Acta Med Scand 1975, 198:445-451.

2. Cha TD, An HS: Cervical spine manifestations in patients with inflammatory arthritides. Nat Rev Rheumatol 2013, 9:423-432.

3. Sternby $\mathrm{NH}$ : Atherosclerosis in a defined population. An autopsy survey in Malmö, Sweden. Acta Pathol Microbiol Scand 1968:5+.

4. Ogren M, Bergqvist D, Eriksson H, Lindblad B, Sternby NH: Prevalence and risk of pulmonary embolism in patients with intracardiac thrombosis: a 
population-based study of 23796 consecutive autopsies. Eur Heart J 2005, 26:1108-1114.

5. Sternby NH: The role of autopsy in cancer registration in Sweden, with particular reference to findings in Malmö. IARC Sci Publ 1991, 112:217-222.

6. Berge T, Lundberg S: Cancer in Malmö 1958-1969. An autopsy study. Acta Pathol Microbiol Scand Suppl 1977, 260:1-235.

7. Östberg G: Temporal arteritis in a large necropsy series. Ann Rheum Dis 1971, 30:224-235.

8. Östberg G: Morphological changes in the large arteries in polymyalgia arteritica. Acta Med Scand Supp/ 1972, 533:135-159.

9. Vasculitis Clinical Research Consortium, Grayson PC, Maksimowicz-McKinnon K, Clark TM, Tomasson G, Cuthbertson D, Carette S, Khalidi NA, Langford CA, Monach PA, Seo P, Warrington KJ, Ytterberg SR, Hoffman GS, Merkel PA: Distribution of arterial lesions in Takayasu's arteritis and giant cell arteritis. Ann Rheum Dis 2012, 71:1329-1334.

10. Koivuniemi $R$, Leirisalo-Repo $M$, Suomalainen $R$, Piirainen $H$, Paimela L: Infectious causes of death in patients with rheumatoid arthritis: an autopsy study. Scand J Rheumatol 2006, 35:273-276.

11. Koivuniemi R, Paimela L, Suomalainen R, Leirisalo-Repo M: Amyloidosis as a cause of death in patients with rheumatoid arthritis. Clin Exp Rheumatol 2008, 26:408-413.

12. Koivuniemi R, Paimela L, Suomalainen R, Piirainen H, Karesoja M, Helve T, Leirisalo-Repo M: Causes of death in patients with rheumatoid arthritis autopsied during a 40-year period. Rheumatol Int 2008, 28:1245-1252.

13. Burton EC, Mossa-Basha M: To image or to autopsy. Ann Intern Med 2012, 156:158-159.

14. Vadillo M, Pujol RP, Corbella X, Gorriz T, Rabasa P, Bernat R: Improvements in clinical diagnostic accuracy after a 5 -year systematic analysis of clinical and autopsy discrepancies. Arch Pathol Lab Med 2006, 130:1261-1262.

15. Christe A, Flach P, Ross S, Spendlove D, Bolliger S, Vock P, Thali MJ: Clinical radiology and postmortem imaging (Virtopsy) are not the same: specific and unspecific postmortem signs. Leg Med (Tokyo) 2010, 12:215-222.

16. Roberts IS, Benamore RE, Benbow EW, Lee SH, Harris JN, Jackson A, Mallett S, Patankar T, Peebles C, Roobottom C, Traill ZC: Post-mortem imaging as an alternative to autopsy in the diagnosis of adult deaths: a validation study. Lancet 2012, 379:136-142.

doi:10.1186/ar4418

Cite this article as: Wollheim: Messages from the morgue to

rheumatology: from Chagas disease to giant cell arteritis. Arthritis Research \& Therapy 2013 15:131. 